\title{
Development of a Health Attitude Scale for Primary School Students
}

\author{
Fatma CILDIR PELITOGLU, Sami OZGUR* \\ Balikesir University, Balikesir, TURKEY
}

Received: 18.02 .2012

Accepted: 16.04 .2013

\begin{abstract}
Health is one of the most fundamental elements of life and health education is increasing its importance each day. The manner health education influences students especially in primary education, where the foundations of education are laid, is an important topic. When the health education curriculum in primary schools is examined in general, it can be observed that it is in the form of an interim discipline embedded in various disciplines. Health education influences students in various aspects through various disciplines by means of various teachers. This condition leads to the conclusion that the attitude and behavior acquired by the student in primary education regarding health influences his/her life in the future in various forms. Based on all these assumptions, the purpose of the study is to develop an attitude scale in order to determine the attitudes of primary school students on health. In this context, the stages required for the preparation and development of a scale have been followed respectively. The validity analyses of the scale were performed and its reliability was determined. Furthermore, the differences between the mean scores of the lower $27 \%$ and upper $27 \%$ groups were tested with the unrelated $t$ test. As a result, by consulting expert opinions a valid and reliable 34 item student health attitude scale was attempted to be developed.
\end{abstract}

Key words: Health, health education, health attitude scale, primary education, student.

DOI No: http://dx.doi.org/10.12973/nefmed152

\section{Summary}

In 1948 the World Health Organization (WHO) defined health as "a state of complete physical, mental, and social well-being and not merely the absence of disease or infirmity" (WHO, 1998). Different perspectives on health and health education in recent years are striking. Current approaches providing health responsibility to individuals such as especially improving health have become more popular.

\footnotetext{
${ }^{*}$ Corresponding author: Sami OZGUR, Assist. Prof. Dr. in Biology Education, Balikesir University, Necatibey Education Faculty, Balikesir, TURKEY.

E-mail: samiozgur@yahoo.fr
}

Note: This study is a part of Fatma CILDIR PELITOGLU Phd dissertation. 
Having the individual acquire the responsibility of health accompanied by international and national policies requires a challenging and long process. In this scope, significant activities should be conducted in the field of education. Attitudes and behaviors acquired in the primary education level, in which the personality of the individual is shaped, can influence the life of the individual in future years. In this context, special emphasis should be laid on health education in the primary education level and various content areas should be determined in different countries or even different regions. For instance, according to Yarham (1994) in a school health education program eight areas of content should be determined. In brief this study can provide information regarding student attitudes to studies to be conducted in the field of health education, which has an extensive scope.

\section{Purpose of the Study}

Determining the attitudes of students on health formed as a result of health education provided in Turkey at a primary educational level and developing a scale regarding these attitudes.

\section{Significance of the Study}

Health education in the primary education curriculum is in the form of an interim discipline. Thus, this education is provided to students through various disciplines and various teachers. In such a case, it is important whether or not there is a determined and practiced common approach regarding health education and whether or not there is an influence of various movements. A manner of learning this is to observe the attitudes of students on health and health education.

\section{Process of Preparation and Development of the Student Health Attitude Scale}

The study consists of two stages. The first one of these is to collect information on what the attitudes of primary education students are regarding health. The other is testing to what extent these statements measure the attitudes in the minds of students towards health.

The first stage of the study consists of attempts of determining existing attitudes of primary school students on health. In the following stage, these attitudes have been transformed into a measurable form. For this purpose, planning and implementation was conducted in a manner covering the phases required for the development of an attitude scale. To this end, first of all an item pool was composed. Afterwards, the items selected from this item pool were converted into a three point Likert type scale. This scale was implemented to 234 randomly selected students in the $6^{\text {th }}$ and $7^{\text {th }}$ grades from three schools in the central district of Balıkesir and villages affiliated to the central district. 
In the validity works of the scale, the scope and structure validity was tested. With regards to the scope validity, during the determination of the attitude statements, the obtained expert opinions were considered suitable and sufficient. For the purpose of revealing the structural validity of the scale, the exploratory factor analysis was utilized. As a result of these analyses, it was observed that the scale consisted of the three factors of "Health Responsibility", "Environment and Safety Health", and "The Whole Human Health".

Regarding the reliability and validity works of the scale the Cronbach alpha coefficient, which is suitable for use with Likert type scales, was calculated as 0.968. In such a case, it can be said that the items constituting the scale are consistent with each other. However, the alpha coefficient is not adequate on its own. In addition to this, the effect of each item to this coefficient was analyzed and with the opinions of experts, it was deemed appropriate for each item to be in the scale.

With the conducted item analysis, the difference between the item averages of the lower $27 \%$ and upper $27 \%$ groups constituted according to the total score of the scale was compared with the independent group $t$ test. It was concluded that the difference between the groups at the 0.05 significance level was important and that it would be suitable for the items to stay in the scale as they are. As a result of the validity and reliability analyses performed in this context and the obtained expert opinions a 34 item health attitude scale was developed.

As a result of conducted analyses, it can be said that this scale developed for determining the attitudes of students towards health education is relevant to the measurement instrument and represents the area that is desired to be measured. Even though an exploratory factor analysis was conducted under the scope of the study for the structural validity of the scale, confirmatory factor analyses should be conducted for the purpose of more detailed analyses. It would be appropriate if the study was repeated at different grade levels and different settings and new data are added to the study.

In the next stage, more detailed studies should be conducted on whether or not there is a determined and implemented approach to health education in Turkey and if so, how this reflects to the student. 


\title{
İlköğretim Öğrencileri İçin Sağlık Tutum Ölçeği Geliştirilmesi
}

\author{
Fatma ÇILDIR PELİTOĞLU, Sami ÖzGÜR ${ }^{\dagger}$ \\ Balıkesir Üniversitesi, Balıkesir, TÜRKİYE
}

Makale Gönderme Tarihi: 18.02.2012

Makale Kabul Tarihi: 16.04.2013

Özet - Sağlık, hayatın en temel öğelerinden biriyken sağlık eğitimi her geçen gün daha da önem kazanmaktadır. Özellikle eğitimin temellerinin atıldığı ilköğretimde sağlı eğitiminin öğrenciyi nasıl etkilediği önemli bir konudur. İlköğretim programlarındaki sağlık eğitimine genel olarak bakıldığında, farklı disiplinlere yerleştirilmiş bir ara disiplin olarak yer aldığı görülmektedir. Sağlık eğitimi, farklı öğretmenler tarafından farklı disiplinler aracılığı ile öğrenciyi farklı açılardan etkilemektedir. Bu durum, öğrencinin ilköğretimde kazandığı sağlığa yönelik tutum ve davranışlarının ileriki yaşantısını farklı şekillerde etkileyebileceği sonucunu doğurmaktadır. Tüm bu varsayımlardan hareketle çalışmanın amacı, ilköğretim öğrencilerinin sağlı̆̆ yönelik tutumlarını tespit etmek için bir tutum ölçeği geliştirmektir. Çalışmanın ilk aşamasında, ilköğretim öğrencilerinin sağlığa yönelik tutumları belirlenmeye çalışılmıştır. Sonraki aşamada bu tutumlar ölçülebilir bir forma dönüştürülmüştür. Bu amaçla önce bir madde havuzu oluşturulmuştur. Daha sonra bu madde havuzundan seçilen maddeler, üçlü Likert tipi bir ölçeğe dönüştürülmüştür. Balıkesir merkez ve merkeze bağlı köy okullarından rastgele seçilen üç ilköğretim okulunda 6 ve 7. Sınıftan 234 öğrenciye bu ölçek uygulanmıştır. Ölçeğin geçerlik çalışmasında kapsam ve yapı geçerliği sınanmıştır. Kapsam geçerliği için tutum ifadelerinin belirlenmesi sırasında alınan uzman görüşleri uygun ve yeterli sayılmıştır. Ölçeğin yapı geçerliliğini ortaya koymak amacı ile açımlayıcı faktör analizi yapılmıştır. Bu analizler sonucunda ölçeğin "Sağlık Sorumluluğu”, "Çevre ve Güvenlik Sağlığı” ve "Bütünüyle Sağlıklı Bir İnsan” olmak üzere üç faktörden oluştuğu görülmüştür. Ölçeğin Cronbach alpha katsayısı 0.968 olarak hesaplanmıştır. Madde ayırt ediciliklerinin belirlenmesi için \%27’lik üst-alt grup tekniği ile analiz yapılmıştır. Bu bağlamda yapılan geçerlik ve güvenirlik analizleri ve alınan uzman görüşleri neticesinde 34 maddelik bir sağlık tutum ölçeği ortaya çıkmıştır.

Anahtar kelimeler: Sağlık, sağlık eğitimi, ilköğretim, öğrenci, tutum ölçeği.

\footnotetext{
† İletişim: Sami ÖZGÜR, Yard. Doç. Dr., Biyoloji Eğitimi A.B.D, OFMA Eğitimi Bölümü, Necatibey Eğitim Fakültesi, Balıkesir Üniversitesi, Balıkesir, TÜRKIYE.

E-posta: samiozgur@yahoo.fr
}

Not: Bu çalışma Fatma ÇILDIR PELİTOĞLU’ nun doktora tezinin bir bölümüdür. 


\section{Giriș}

Sağlıklı olmak ve nesli sağlıklı bir şekilde devam ettirmek içgüdüsü canlıların pek çok davranışına şekil verdiği gibi toplumsal bir nitelik de kazanmıştır (Akdur, 2003). Sağlığa nereden ve nasıl bakıldığına bağlı olarak çeşitli felsefe ve yaklaşımlar ortaya çıkmıştır. Sağlık, yalnızca sağlık hizmet sektörünün değil pek çok sektörün ortaklaşa çalıştığı, ulusal ve uluslararası politikalarla düzenlenen toplumsal bir davranış haline gelmiştir.

Türkiye Cumhuriyeti Anayasası 56. maddesi (1982) Sağlık Hizmetleri ve Çevrenin Korunması başlığında "Herkes sağlıklı ve dengeli bir çevrede yaşama hakkına sahiptir. Çevreyi geliştirmek, çevre sağlığını korumak ve çevre kirlenmesini önlemek devletin ve vatandaşların ödevidir” demektedir (Türkiye Cumhuriyeti Anayasası, 56. Madde, 1982).

İnsan ve toplum hayatında önemli bir yere sahip olan "Sağlık”, 1948'de Dünya Sağlık Örgütü (DSÖ) tarafindan, "Yalnız hastalık ve sakatllğın olmaması durumu değil; bedensel, zihinsel ve sosyal yönlerden de tam bir iyilik hali" olarak tanımlamıştır (WHO, 1998). Günümüzde sağlığın kapsamı genişletilerek bedensel boyutunun yanı sıra ruhsal, psikolojik, sosyolojik boyutları da eklenmiştir (Doğan, 2006). Genel olarak sağlı; psikolojik ve fiziksel olarak sağlam olma, organların tam ve sağlıklı çalışması, ruhsal sağlığın dengeli olması halidir (Zöllner, Stoddart \& Selby Smith, 2003).

Ülkelerin bilim toplumu düzeyine ulaşabilmeleri ve bu gelişmişliği devam ettirebilmeleri için sağlıklı bireylere sahip olması gerekir. Sağlıklı bireylere sahip olmak için ise etkili bir sağlık eğitiminin günlük hayata geçirilmesi gerekmektedir (MEB, 2012). Günümüzde sağlık, bilinçli ve planlı bir eğitim süreci ile birey ve toplum hayatında yer almaktadır. Dünya Sağlık Örgütü (DSÖ) “Sağlık Eğitimi”ni kapsamlı olarak şöyle tanımlamaktadır; "Sağglk eğitimi, bireylere ve topluma sağlıklı yaşam için alınması gereken önlemleri benimsetip uygulatmak, sunulan sağlık hizmetlerini kullanmaya alıştırmak, sağlıklarını ve çevrelerini iyileştirmek için insanları ikna etmek, ortak karara vardırmak ve eyleme yöneltmek amacıyla gerçekleştirilen eğitim uygulamalarıdır” (WHO, 1998; 2013a) (Alkan, Ertem, Hatemoğlu, Hülür ve Mollahaliloğlu, 2005).

Modernizm öncesi yaklaşımlarda aileler, sağlıkla ilgilenen temel kurumlardı ve fiziksel yöntemlerin yanı sıra doğaüstü pratikler de önemli ölçüde kullanılmaktaydı. Modernizmin etkisiyle, bilimsel bilgi hızla yaygınlaşmış ve birey sağlık kontrolünü tümüyle uzmanların eline bırakmıştır. Daha sonra postmodern yaklaşımların ortaya çıkmasıyla, bireylerin sağlık bilinci gündeme gelmeye başlamıştır (Man ve Balc1, 2006). 
Günümüzde hastalıklardan korunmak ya da hastalıkların tedavisi yerine sağlığın nasıl geliştirileceği konusu gündemdedir. Özellikle sağlık eğitiminde sağlık bilincine vurgu yapan “Sağlığın Geliştirilmesi ve Teşviki (Health Promotion)” kavramı öne çıkmaktadır. Dünya Sağlık Örgütü Avrupa Bölge Ofisi tarafından ilk kez önerilmiş ve Birinci Uluslararası Sağlığın Teşviki ve Geliştirilmesi Konferansında onaylanıp Ottawa Sözleşmesinde yayımlanmış ve "İnsanların kendi sağlıkları üzerindeki kontrolü arttırmalarını ve böylece sağlıklarını geliştirmelerini sağlama süreci” şeklinde tanımlanmıştır (Rootman, 2011). Sağlığ1 geliştirme, DSÖ tarafından "insanların kendi sağlıklarını kontrol etmeyi ve geliştirmeyi arttırmaya olanak sağlayan bir süreç” olarak tanımlanmaktadır. Bu süreci başarıyla uygulayan insan sağlıklıdır. Genel olarak bakıldığında sağlığı geliştirme, insanların en uygun sağlık koşullarına ulaşmaları için yaşam sitillerini değiştirmelerine yardım etme bilimi ve sanatıdır (WHO, 1998; 2013b) (Kaya, Ünüvar, Bıçak, Yorgancı, Funda Öz ve Kankaya, 2008). Fiziksel, ruhsal ve sosyal anlamda iyi olma durumunu sağlayabilmek için birey veya grup; isteklerinin farkında olmalı, çevreyi değiştirebilmeli ve çevreyle uyum sağlayabilmelidir (Fosse ve Roeiseland, 1999). Pender'e göre sağlığı geliştirme; iyilik düzeyini arttırma ve bireyin, ailenin ve toplumun sağlık potansiyelini üst düzeye çıkarma aktiviteleri olarak görülmektedir (Srof ve Velsor-Friedrich, 2006).

Farklı şekillerde tanımlansa bile sağlığı geliştirmenin genel özelliği, sağlık konusunda söz hakkını öncelikle topluma ve dolayısı ile de bireye vermesidir. Bu bilinci, sağlıkla ilgili görülen ya da görülmeyen tüm sektörlerin işbirliği ile bir plan ve program çerçevesinde hayata geçirmeyi hedeflemektedir. Bu güncel sağlık eğitimi yaklaşımına sahip bir birey kendi sağlığından olduğu kadar çevresinin sağlığından da sorumlu ve yetkilidir. Man ve Balcı (2006) bunu, postmodern yaklaşımların sağlık bilincini gündeme getirmesi olarak açıklamaktadır. Bu durum geleneksel sağlık eğitimi yaklaşımlarında görülmez. Çünkü geleneksel bakış açısına sahip birey, kendi ve çevresinin sağlığından sorumlu olmaz. Bu sorumluluğu ve yetkiyi kendisinin dışındaki unsurlara verir. Geleneksel sağlık eğitimi bakış açısında koruyucu, önleyici ve tedavi edici hizmetlerle sağlık eğitimi verilir ve birey sağlığından doğrudan sorumlu değildir.

Sağlığı geliştirmede sadece bilgileri öğrenmek değil aynı zamanda bunu bir yaşam tarzı haline getirmek önemlidir. Dolayısıyla sağlık eğitimi, belli bir plan ve program çerçevesinde, sağglı bilincini hayata geçirecek şekilde olmalıdır. Bir sağlık eğitimi programı geliştirilirken; sağlık alanına özgü süreç ve eğitim süreci ortaklaşa vurgulanmalıdır. Müzakere, planlama, etkileşim, duyarlılık, karar verme, analiz, kritik düşünme, dinleme, problem çözme, kişisel 
seçim, değerlendirme, ortak çalışma, iletişim gibi yaşam becerilerinin metodolojisi programın her alanına uygulanmalıdır. Sağlık eğitimi ile öğrenciye karar vermeyi öğretmek, özsaygılarını inşa etmelerini desteklemek ve gelecekteki firsatları yakalayabilmeleri için yaratıcılıkla donatmak gerekmektedir. Tüm seviyelerinde düzenli bir yaklaşımla öğrenci, kendi kişisel duyarlılığını ve özsaygısını arttırabilmelidir. Bunun yanı sıra bazen kriz odaklı yaklaşımlarla belli bir konu üzerine gidilebilmelidir. Örneğin, HIV/AIDS gibi konularda okullarda özel eğitimler verilebilmelidir. Ancak bu konular okullarda süregelen sağlık eğitimi programlarının bir parçası olmalıdır. Sağlık eğitimi, yapısı gereği güncel veriler ışı̆̆ında revize edilmeye muhtaçtır. Sağlık eğitiminde; toplumsal bir düzenlemeye gitmeye, tutumlara vurgu yapmaya ve davranış değişikliğine gitmeye odaklanan metotlar kullanılmalıdır. Bu gibi durumlarda yenilikçi öğretim metotları, strateji ve teknikleri, uygun eğitim desteği gereklidir. Eylem odaklı bu programda fikirler, tutumlar, bilgiler ve beceriler toplanmalıdır (Yarham, 1994).

Bu bağlamda Yarham (1994) sekiz içerik alanına sahip, sarmal bir okul sağlık eğitimi programı önermiştir. Bu içerik alanları; bütünüyle sağlıklı bir insan, sağlık sorumluluğu, sosyal sağlık, güvenlik sağlı̆̆1, çevresel sağlık, beslenme sağlığı, ilaçlar, tüketici sağlığ1 olarak sıralanabilir. Bu kapsamda verilen örnek sağlık eğitimi programında yer alan sekiz içerik alanı, sağlık eğitimine yönelik tutumların belirlenmesinde araştırmaya kaynak olmuştur.

Pender'in Sağglı̆̆ Geliştirme Modeline dayandırılarak, bireylerin sağlığı geliştirme davranışlarını ölçmek için Walker ve arkadaşları (1987) tarafından Sağlığı Geliştirme Yaşam Stili ölçüm aracı geliştirilmiştir. Bu ölçek 1996'da Walker ve arkadaşları (1996) tarafından tekrar revize edilerek 52 maddelik Sağlıklı Yaşam Biçimi Davranışları Ölçeği II oluşturulmuştur. Bu ölçek; manevi gelişim, kişilerarası ilişkiler, beslenme, fiziksel aktivite, sağlık sorumluluğu ve stres yönetimi olmak üzere altı faktörden oluşmaktadır (Bahar, Beşer, Gördes, Ersin ve K1ssal, 2008).

Türkiye'de sağlık eğitimi hakkında önemli çalışmalar yapılmaktadır. Bu çalışmaların bir kısmı sağlık eğitiminin var olan durumunu ortaya koymakta ve öneriler sunmaktadır. Örneğin Alkan ve arkadaşları (2005), okullardaki sağl1k eğitimi hakkında mevcut durum raporu hazırlamışlardır. Bu rapora göre kapsamlı bir okul sağlık eğitimi programının nasıl olması gerektiği üzerinde durulmuştur. Okul sağlık öğretim programı okul öncesi dönemde başlayan ve orta öğretimin sonuna kadar süren planlı ve aşamalı bir programdır. $\mathrm{Bu}$ programda güdüleme ve davranış değiştirmenin öne çıkarılması ve olumsuz ortamın yanı sıra akran baskı ve etkileri ile de mücadele edilmesi gerekliliği vurgulanmıştır. 
Kaya ve arkadaşları (2008) tarafından sağlığı geliştirme davranışları üzerine yapılan çalışmada öğretim elemanları incelenmiş ve öğretim elemanlarının sağlığı geliştirme ile ilgili davranışlarının genel olarak orta düzeyde olduğu tespit edilmiştir.

Üniversite öğrencilerinin iyilik halini araştıran Doğan (2006) çalışmasında, ailelerinden ve arkadaşlarından yeterince destek gören, fiziksel egzersiz yapan ve kendi geleceklerine ilişkin olumlu düşüncelere sahip üniversite öğrencilerinin iyilik halinin daha yüksek olduğunu saptamıştır.

Cerrah ve Ayaş (2003) tarafından yapılan araştırmada, meslek liselerinde görev yapan biyoloji öğretmenlerine anket uygulanmış ve ankete katılanların büyük çoğunluğunun öğrencilerin sağlık konusundaki bilgilerinin yetersizliğinden dolayı ayrı bir Sağlık Bilgisi dersinin gerekli olduğunu vurguladıkları belirtilmiştir.

Sağlam (1996), ortaöğretimde Sağlık Bilgisi dersinin niteliği ve öğrencilerin bu derse ilgilerini saptamaya yönelik çalışmıştır. Örneklemdeki öğrencilerin ilgileri, Sağlık Bilgisi dersinin içeriği, dersin işleniş biçimi, öğretmen ve öğrencilerin ders ile ilgili karşılaştıkları sorunlar araştırılmıştır. Çalışma kapsamında, öğretmen ve öğrencilerin çoğunun, Sağlık Bilgisi dersinin öğretim ve öğreniminin yetersizliğine vurgu yaptığı ortaya çıkmıştır. Dersin verimini engelleyen unsurlar olarak; öğretmenin bilgi yetersizliği, biyoloji dersi konularıyla çakışması ve dolayısıyla teorik bilginin yeterince verilememesi, pratik uygulamalarla desteklenememesi gibi nedenler ortaya konmuştur. Dolayısıyla öğrencilerin, sağlıkla ilgili bazı konulara ilgisinin azaldığı dile getirilmiştir.

Ortaöğretimde sağlık eğitiminde bu problemler görülüyorsa ilköğretimde durumun nasıl olduğu, bir ara disiplin olarak öğrencileri nasıl etkilediği, öğrencilerin kendilerinin ve çevrelerinin sağlığı hakkında sorumluluk alıp alamadıkları ve sağlık eğitimine yönelik tutumlarının tespiti önemlidir. Bireyin bir konu ya da derse yönelik duyuşsal özelliklerinin ve özellikle geliştirdiği tutumların eğitim ve öğrenme açısından önemi bilinmektedir. Tutumların belirlenmesi için ise fizyolojik tepkilerden vardama, açık davranışlardan vardama ve ölçek geliştirmeden faydalanılır (Kan ve Akbaş, 2005). Bu araştırmada da tutumların belirlenmesi için bir sağlık ölçeği geliştirilmeye çalışılmıştır.

\section{Araştırmanın Amacı}

$\mathrm{Bu}$ çalışmanın amacı; Türkiye'de ilköğretim 1-8. sınıf düzeyinde, çeşitli disiplinler kapsamında verilen sağlık eğitimine yönelik etkinlikler sonucu öğrencilerde oluşan sağlıkla ilgili tutumları tespit etmek ve bunlarla ilgili bir tutum ölçeği geliştirmektir. 
Çalışma iki aşamalıdır. Bunlardan birincisi ilköğretim öğrencilerinin sağlıkla ilgili tutumlarının neler olduğuna dair bilgi toplamaktır. Diğer aşama ise belirlenen bu ifadelerin öğrencilerin zihnindeki sağlığa karşı tutumu ne derece ölçtüğünün test edilmesidir.

\section{Araştırmanın Önemi}

Türkiye'de ilköğretim seviyesinde sağlık eğitimi, öğretim programlarında "Sağlık Kültürü Eğitimi” adı altında ara disiplin olarak temsil edilmektedir ve kendi kazanımları vardır (MEB, 2009). Öğrenciye, farklı disiplinlerde ve dolayısıyla farklı öğretmenler tarafindan sağlık eğitimi verilmektedir. Bu durumda sağlık eğitimi ile ilgili belirlenmiş ve uygulanan ortak bir yaklaşımın olup olmadığı, farklı akımların etkisinin görülüp görülmediği önemlidir. Bunu öğrenmenin bir yolu da öğrencilerin sağlık ve sağlık eğitimine yönelik sahip oldukları tutumlara bakmaktır. Bu amaçla öğrencide sağlığa yönelik tutumları tespit etmek için bir tutum ölçeği geliştirilmeye çalışılmıştır.

\section{Yöntem}

Bireyler hakkında karar verirken duyuşsal özelliklerinin ölçülmesine ihtiyaç duyulabilir. Duyuşsal özelliklerin öğrenilmesi hem duyuşsal özelliklerin öğretilmesi hem de öğrenilen duyuşsal özelliklerin bilişsel ve psikomotor davranışların öğrenilmesinde veya öğretilmesinde bir araç olarak kullanılması bakımından önemlidir. Örneğin, bireyin sağlığa karşı olumsuz tutumu varsa sağlık konusunda eğitim vermek zorlaşır. Duyuşsal özelliklerin ölçülmesinde kullanılan araçlar, bireyler arasındaki farkları ya da aynı kişinin farklı zaman ve durumlardaki tepki farklarını belirlemede kullanıldığı için geçerli ve güvenilir olmalıdır. Bu da planlı, sistemli ve yönteme dayalı çalışmalarla elde edilebilir. Duyuşsal özellikleri yansıtan yapılardan bazıları tutum, kendini algılama, ilgi ve değerlerdir (Tekindal, 2009).

\section{Öğrenci Să̆llk Tutum Ölçeğinin Hazırlanması ve Geliştirilmesi Süreci}

İlköğretim öğrencileri için Sağlık Tutum Ölçeği hazırlama çalışması dört aşamada gerçekleştirilmiştir. Bu aşamalar; ölçek maddelerini belirleme, deneme ölçeğini hazırlama, deneme ölçeğini uygulama, geçerlilik ve güvenirliliği belirleme olarak adlandırılmıştır.

Birinci Aşama: Maddelerin Belirlenmesi

Çalışmanın ilk adımı olarak, tutum ölçeği geliştirme aşamaları ile ilgili literatür (Çirkinoğlu-Şekercioğlu, 2011; Güven ve Uzman, 2006; İslamoğlu ve Börü, 2007; Koçakoğlu ve Türkmen, 2010; Terzi ve Tezci, 2007; Turan ve Bahar-Özvarış, 2006; Yeşilyurt ve Gül, 2009) ve sağlı eğitimi ile ilgili literatürden örnekler gözden geçirilmiştir (Güler ve Yöndem, 
2007; McQueen ve Jones, 2007; Tokuç ve Berberoğlu, 2007; Ulusoy-Gökkoca, 2001; Whalen, Splendorio ve Chiariello, 2007; Yarham, 1994; Yurtsever-Kılıçgün ve Oktay, 2011).

Maddeleri belirleme aşamasında öğrencilerin sağlığa yönelik tutumlarıyla ilgili olarak Balıkesir merkez ve merkeze bağlı bir köy okulu olmak üzere iki İlköğretim okulundan bilgi toplanmıştır. Bu amaçla 6 ve 7. sınıf öğrencilerinden oluşan 117 kişilik bir ön-uygulama grubuna hazırlanan bir resim yorumlatılmış, açık ve kapalı uçlu sorular sorulmuştur. Yanıtların analizi ile tutum ifadeleri için önemli ipuçları elde edilmiştir. Ön çalışma yanıtlarından elde dilen verilerden, uzman görüşlerinden ve araştırmacıların düşüncelerinden faydalanarak 65 maddelik bir havuz oluşturulmuştur. Ölçek geliştirme ilkeleri de dikkate alınarak hazırlanan bu madde havuzu, Türkiye'nin kültürel yapısı ve sağlık eğitim politikaları da göz önünde bulundurularak hazırlanmış denemelik tutum maddelerinden oluşmaktadır.

Yarham'ın (1994), sağlık eğitiminde bahsettiği sekiz alt kategori araştırma amacına yönelik olarak uyarlanmış ve didaktiksel bakış açısı kategorisi de eklenerek ölçeğin alt boyutları oluşturulmuştur. Böylece maddeler, çalışma amacına uygun dokuz alt boyut altında gruplanmıştır. Araştırmanın doğasına uygun olarak bu boyutlar; bütünüyle sağlıklı insan, güvenlik sağlığı, sağlık sorumluluğu, çevresel sağlık, sosyal sağlık, beslenme sağlığı, tüketici sağlığı, ilaçlar ve zararlı alışkanlıklar, diğer (eğitim-öğretim) didaktiksel bakış açısı olarak şekillenmiştir. Sözü edilen dokuz boyut geleneksel sağlık eğitimi ve güncel sağlık eğitimi yaklaşımlarını temsil edecek şekilde düzenlenmiştir.

Havuzdaki maddeler, 110 kişiye uygulanan ön-deneme çalışması sonucu tekrar gözden geçirilmiş ve uzman görüşü de alınarak 57 maddelik denemelik tutum ölçeği hazırlanmıştır.

\section{İkinci Aşama: Deneme Ölçeğinin Hazırlanması}

Deneme ölçeğini hazırlama aşamasında tutum ifadeleri, biçimsel ve ifade bakımından ölçeğe uygun maddeler haline getirilmiştir. Belirlenen bu 57 madde, 3'lü Likert formatında yanıtlandırılacak şekilde (1=Katılıyorum, $\quad 2$ =Kararsızım, $\quad 3=$ =Katılmıyorum) derecelendirilmiştir. Ölçeğin maddelerinin olumlu-olumsuz şekilde ve davranış-düşünceduygu boyutlarında eşit olarak temsil edilmesine dikkat edilmiştir. Ölçeği yanıtlayanları yönlendirmemek adına olumlu-olumsuz maddeler karışık olarak sıralanmıştır. Aynı şekilde maddeler davranış-düşünce-duygu boyutlarında da karışık olarak temsil edilmektedir. Alan uzmanlarının ve Türkçe alanında bir dil uzmanının kontrolünden de geçirilerek 57 maddelik deneme formu hazırlanmıştır (Tablo 1). 
Tablo 1: Deneme Ölçeğinde Yer Alan Maddeler

1 Kendi kişisel bakım ve temizliğimi kendim yaparım

2 Çöplerimi her zaman ayrıştırarak bir çöp kutusuna atarım

3 Alışverişe gitmeden önce alınacakları listelerim

4 Sağlığıma zarar veren bir kötü alışkanlığım yoktur

5 Bazen dişlerimi firçalamak zor gelir ve firçalamam

6 Sağlıkla ilgili ayrı bir dersim olmasını isterim

7 Genetiği değiştirilmiş bitki yersek bizim de genlerimiz değişisir

8 Zamanı gelince aşılarımı olurum

9 Biten pilleri her zaman pil atık kutusuna atarım

10 Hasta olmasam da doktora kontrole giderim

11 Çocuk olarak haklarımı biliyorum

12 Bana hediye olarak sağlıkla ilgili kitap verilmesinden hoşlanırım

13 Tehlikeli sokak aralarında arkadaşlarımla oyun oynamam

14 Kadın ve erkek eşit haklara sahiptir

15 Hastalanınca doktora gitmeden evdeki ilaçları kullanırım

16 Geri dönüşümü dikkate alır, çöplerimi ayrıştırırım

17 Vücudumu seviyorum

18 Obezite (aşırı kilo) sorunu hakkında bilgi sahibiyim

19 Kendi güvenliğimden sorumlu değilim

20 Sadece ekonomik öneme sahip bitki ve hayvanlar korunma altına alınmalıdır

21 Kendi sağlığım kadar çevremdekilerin sağlığına da önem veririm

22 İlaçlar vücutta sadece hasta olan bölgeye etki eder

23 Spor yapmak bana zor gelir

24 Sağlıklı olmak için yapmam gerekenleri bilmiyorum

25 Bence bu geri dönüşüm olayını fazla abartıyorlar

26 Öğretmenler okulda cinsel eğitim vermemeli çünkü bu konular özeldir

27 Sağlık konularının okulda öğrenmeyi gerektirecek kadar önemli olduğunu düşünmüyorum

28 Bazı insanların kendilerini diğerlerinden üstün görmeleri beni sinirlendirir

29 Arabaya bindiğimde mutlaka emniyet kemerimi bağlarım

30 Kendi sağlığıma önem verdiğime inanıyorum

31 Psikolojisi bozuk biri de sağlıklı olabilir

32 Doğa her zaman kendini yeniler

33 Bir insan bana kaba davrandığında ona aynı şekilde karşılık vermem

34 Aşı olunca hasta olmam

35 En pahalı ürün her zaman en sağlıklı olandır

36 Sağlıkla ilgili okulda öğrendiğim konuların günlük hayatta işime yarayacağını düşünmüyorum

37 İnsanların diğer canlılara karşı sorumluluğu vardır

38 Trafik kurallarına sadece sürücüler uymak zorundadır

39 Dünyanın sınırsız doğa kaynakları vardır

40 Fakirler, sağlıkları konusunda zenginler kadar bilinçli değildir

41 İnsanların kendi sağlıklarına karşı sorumlulukları vardır

42 Derslerde sağlıkla ilgili daha fazla bilgi verilmesine gerek yok

43 Sağlıklı olmak için hastalıklardan korunmak gerekir

44 Dişlerimi fırçalarken suyun boşa akmasının kimseye zararı olmaz

45 Genelde yiyecek yada içecek alırken son kullanma tarihine bakmam

46 Televizyonu kumanda ile kapatırım

47 Kendi sağlığım hakkında karar veremem

48 Kadınlar erkeklerden daha az zekidir çünkü beyinleri erkeklerden daha küçüktür

49 Bisiklete binerken kask takmam

50 İnsanların diğer canlılara göre genleri daha fazladır

51 Büyüklerimden reklamlarda gördügüum ürünlerin aynısından isterim

52 Sağlığım ile ilgili bilgileri doktordan öğrenmek hoşuma gider

53 Ellerimi yıkamak bana zor gelir

54 İkizlerin genleri aynı olduğu için mikroplara karşı bağışıklık sistemleri de aynıdır

55 Sivı yiyecekler daha hızlı sindirilir

56 Karbon ayak izini bilmiyorum

57 Sağllğımdan anne-babam sorumludur

\section{$\ddot{U} c ̧ \ddot{u n c u ̈ ~ A s ̧ a m a: ~ O ̈ l c ̧ e g ̆ i n ~ U y g u l a n m a s ı ~}$}


Gerekli izinler alınarak uygulama 2011-2012 Eğitim-Öğretim yılı Mayıs ayının 2 ve 3. haftası Balıkesir merkez ve merkeze bağlı köy okullarından rastgele seçilen üç ilköğretim okulunda 6 ve 7. sınıftan 234 öğrenciyle gerçekleşmiştir. Uygulamanın dönem sonuna denk getirilmesi araştırmanın amacına yöneliktir. Ayrı bir sağlık eğitimi dersinin olmaması ve bir ara disiplin olarak farklı derslerde yer alması nedeniyle, konuların hepsini görmelerinin ve bu konudaki eğitimlerini tamamlamalarının daha uygun olacağı düşünülmüştür. Bu uygulamanın 6 ve 7. sınıf öğrencileriyle yapılmasının nedeni, sağlık eğitimiyle ilgili çeşitli konuları görmüş olmaları ve sağlık eğitimine ilişkin tutumlarının oluşmaya başlamasıdır. 8. sınıfların genel sınavlara hazırlanıyor olmalarından dolayı ölçeğin oluşturulmasını etkileyebileceği düşüncesiyle kapsam dışı bırakılmıştır. Uygulama öncesinde öğrenciler bilgilendirilmiş, izinleri alınarak uygulama yapılmıştır. Ölçeğin yanıtlama süresi yaklaşık 30 dakika olarak belirlenmiştir.

\section{Dördüncü Aşama: Geçerlik Analizi ve Güvenirliğin Belirlenmesi}

Ölçeğin uygulanmasının ardından 234 öğrenciden alınan veriler SPSS 16.0 (Statistical Package for Social Science) paket programına girilerek geçerlik analizi yapılmış ve güvenirlik belirlenmiştir. Ölçeğin geçerlik çalışmasında kapsam ve yapı geçerliği sınanmıştır. Kapsam geçerliği için tutum ifadelerinin belirlenmesi sırasında alınan uzman görüşleri uygun ve yeterli sayılmıştır. Ölçeğin yapı geçerliliğini ortaya koymak amacı ile açımlayıcı faktör analizi kullanılmıştır. Faktör analizi, yorumlanması güç birçok ilişkiyi açıklayan birbiriyle korelasyonu olan maddeleri yapısal olarak anlamlı ve bağımsız faktörler altında toplayan çok değişkenli bir analiz tekniğidir. Çok sayıda değişken arasındaki ilişkiye dayanarak verilerin daha anlamlı ve özet biçimde analizini sağlamaktadır (Bay, Mert, Alyılmaz ve Albayrak, 2012; Büyüköztürk, 2004; Ural ve K1lıç, 2006). Gerçekleştirilen faktör analizi sonucunda maddelerin yük değerleri esas alınarak ölçeğin sahip olduğu faktörler ve her bir faktörde yer alan maddeler belirlenmiştir. $\mathrm{Bu}$ faktör analizi sırasında veriler rotasyona tabi tutularak özdeğeri 1'den büyük olan faktörler hesaba katılmıştır. Faktör örüntüsünün oluşturulmasında 0.30 ile 0.40 arasında değişen faktör yüklerinin alt kesme noktası olarak alınabilir (Cathell ve Baggaley,1960; Gorsuch, 1974; Akt: Tavşanc1l, Keser, 2002). Faktör yük değerinin 0.45 veya daha yüksek olması seçim için iyi bir ölçü olsa da uygulamada az sayıda madde için bu sınır değer 0.30'a kadar indirilebilir (Büyüköztürk, 2004). Örneklem sayısının 234 olduğu bu çalışmada anlamlı faktör yüklerinin alt kesme noktası 0.40 kabul edilmiştir. Birden fazla faktörde yüksek yük değerine sahip maddeler ölçekten çıkarılmıştır (Tablo 4). 
Ölçeğin güvenilirlik çalışmaları için Likert tipi ölçeklerde kullanıma uygun olan Cronbach alpha katsayısı hesaplanmıştır (Tablo 5). Ancak alfa katsayısı tek başına yeterli değildir. Buna ek olarak her bir maddenin bu katsayıya etkisi incelenmiştir (Tablo 6).

Madde ayırt edicilik işlemlerinde, ölçeğin toplam puanlarına göre oluşturulan \%27'lik alt grubun ve \%27'lik üst grubun madde ortalamaları arasındaki fark bağımsız grup t-testi ile karşılaştırılmıştır. Her bir maddenin ayırt edicilik indeksine bakılmıştır. $\mathrm{Bu}$ aşamada istatistiksel olarak 0.05 anlamlılık esas alınmıştır (Tablo 7) (Büyüköztürk, 2004).

\section{Bulgular ve Yorumlar}

Faktör Analizine ve Güvenilirlik Analizine İlişkin Bulgular

Ölçeğin $(K=57)$ yapı geçerliliğini sınamak amacıyla yapılan faktör analizi sonucu öncelikle ölçeğin boyutlarıyla ilgili bilgi edinilmiştir. Temel bileşenler faktör analizi çözümlemesi ve Varimax tekniği ile yapılan döndürme işlemi sonunda, özdeğeri 1.00'den büyük olan ve faktör yükü 0.40 'ın üstünde olan maddeler analize katılmıştır. Anlaş1lır, birbirini tekrar etmeyen maddeler seçilmiştir. Uzman görüşleri de alınarak 57 maddelik deneme ölçeğinin 23 maddesi elenerek 34 maddelik ölçek elde edilmiştir.

Ölçeğin $\mathrm{K}=34$ maddelik yeni haline, faktör analizine uygunluğunu tespit etmek için öncelikle Kaiser-Meyer-Olkin (KMO) örneklem yeterliliği testi ve değişkenler arasındaki korelasyon ilişkisini belirlemek için Bartlett testi uygulanmıştır (Tablo 2).

Tablo 2: KMO ve Bartlett's Testi Değerleri

\begin{tabular}{llc}
\hline Kaiser-Meyer-Olkin Örneklem Yeterliliği & 0.955 \\
Bartlett's Testi & Ki-Kare & 6.59 \\
& Serbestlik Derecesi & 561 \\
& $p$ & 0.000 \\
\hline
\end{tabular}

Örneklemin uygunluğu için bulunan KMO değeri 0.955 'tir. $\mathrm{Bu}$ değer, kullanılan verilerin örneklem büyüklüğü açısından faktör analizi için uygun olduğunu göstermektedir. Bartlett Testi sonucunun anlamlı olduğu, yaklaşık ki-kare değeri 6.59; serbestlik derecesinin 561 ve anlamlılığın (p) ise 0.000 olduğu görülmüştür. Bu durumda değişkenler arasında yüksek korelasyonlar olduğu ve verilerin çoklu normal dağılımdan geldiği söylenebilir. Elde edilen bulgular, faktör analizini gerçekleştirebilmek için üzerinde çalışılan örneklem büyüklüğünün yeterli ve verilerin analize uygun olduğunu göstermektedir. 
34 maddelik ölçek temel bileşenler faktör analizi ile değerlendirilmiştir. Ölçme aracındaki maddelerin faktör analizi için uygunluğunu belirlerken madde varyans değerleri, faktörlerin toplam varyansı açıklama oranları ve her bir maddenin faktördeki yük değerlerine bakılmıştır.

Tablo 3: 34 Maddelik Öğrenci Sağlık Tutum Ölçeği İçin Toplam Varyansın Açıklanma Yüzdeleri

\begin{tabular}{ccccccc}
\hline & \multicolumn{3}{c}{ Başlangıç Özdeğerleri } & \multicolumn{2}{c}{ Döndürü̈lmüş Kareli Yüklerin Toplamı } \\
Bileşen & Toplam & Varyans \% & Kümülatif & Toplam & Varyans \% & Kümülatif \\
1 & 17.184 & 50.542 & 50.542 & 8.615 & 25.338 & 25.338 \\
2 & 2.835 & 8.337 & 58.879 & 8.539 & 25.115 & 50.453 \\
3 & 1.764 & 5.189 & 64,068 & 4.629 & 13.615 & 64.068 \\
\hline
\end{tabular}

Yukarıdaki tabloda başlangıç özdeğerlerine bakıldığında döndürme öncesi birinci faktörün yol açtı̆̆ı varyansın \%50.542'sini karşılaması dolayısıyla genel bir faktörün varlığından söz edilebilir (Büyüköztürk, 2004). Döndürme öncesi bileşen matrisinde 30 maddenin birinci faktör yük değerlerinin 0.528 ve üstünde olması ve yamaç eğim grafiğinde birinci faktörden sonra yüksek ivmeli bir düşüşün gözlenmesi de ölçeğin genel bir faktöre sahip olduğunu düşündürmektedir (Büyüköztürk, 2004) (Şekil 1). Ancak bir arada bulunan bu maddeler incelendiğinde anlamlı bir faktör ismi verilemediği için, uzman görüşlerine de başvurularak döndürme sonrası veriler incelenmiştir.

Tablo 3'te görüldüğü gibi Varimax döndürmesine tabi tutulan maddelerin ( $K=34)$ ölçme aracında özdeğeri 1'den yüksek üç faktör altında toplandığg görülmektedir. Döndürme sonras1 ortaya çıkan üç önemli faktörün içerdiği maddeler bakımından daha kolay tanımlanması, bu verilerin tercih edilmesine yol açmıştır. Döndürme sonrası birinci faktörün toplam varyansı açıklama oranı 25.338; ikinci faktörün 25.115 ve üçüncü faktörün 13.615 ve bu üç faktörün toplam varyansı açıklama oran 164.068 'dir. Buna göre analizde önemli faktör olarak ortaya çıkan üç faktörün birlikte, maddelerdeki toplam varyansın ve ölçeğe ilişkin varyansın çoğunluğunu açıkladığı görülmektedir (Tablo 3).

Bu durum Cattel'in "scree" sınaması ile de test edilmiş ve aşağıdaki gibi bir grafik elde edilmiştir (Şekil 1). 


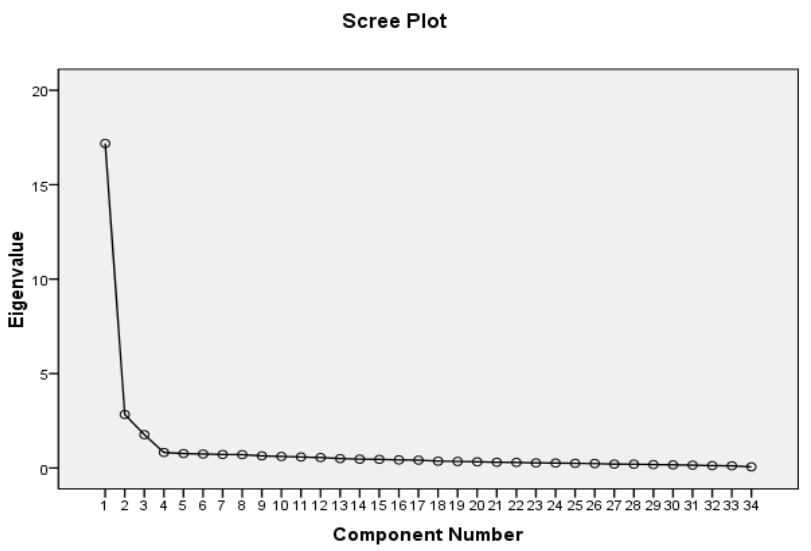

Şekil 1: Faktörlere İlişkin Yamaç Eğim (Scree Plot) Grafiği

Şekil 1'de de görüldügü gibi grafikte birinci faktörden sonra yüksek ivmeli bir düşüş gözlenmektedir. İkinci ve üçüncü faktörlerden sonra da daha az olmakla birlikte ivmeli bir düşüş gözlenmektedir. Dördüncü ve sonraki faktörlerde grafiğin genel gidişi yatay olup önemli bir düşüş eğilimi görülmemektedir. Yani dördüncü ve sonraki faktörlerin varyansa olan katkıları birbirine yakındır. $\mathrm{Bu}$ durum ölçeğin üç faktörlü olarak şekillendiğini düşündürmektedir. Bu üç faktöre ilişkin özdeğerler, varyans yüzdeleri ve toplam varyans yüzdeleri Tablo 3 'te verilmiştir (Büyüköztürk, 2004; Ural ve Kılıç, 2006) (Şekil 1) (Tablo 3).

Yapılan bu faktör analizi sonucunda, toplam varyansın \% 64.068'ünü açıklayan üç faktör bulunmuştur. Bu faktörler; sağlık sorumluluğu, çevre ve güvenlik sağlığı, bütünüyle sağlıklı bir insan şeklinde adlandırılmıştır. Bu faktörler ve faktörlere ilişkin maddelerle ilgili bilgiler Tablo 4'te verilmiştir.

Tablo 4: Öğrenci Sağlık Tutum Ölçeği Faktör Analizi Sonucu Faktörlere İlişkin Elde Edilen Bulgular

\begin{tabular}{lll}
\hline & & \multicolumn{1}{c}{ Faktör 1: Sağlık Sorumluluğu } \\
Madde No & Madde & Faktör Katkıs \\
M 38* & Trafik kurallarına sadece sürücüler uymak zorundadır & 0.749 \\
M 53* & Ellerimi yıkamak bana zor gelir & 0.737 \\
M 20* & Sadece ekonomik öneme sahip bitki ve hayvanlar korunma altına alınmalıdır & 0.721 \\
M 41 & İnsanların kendi sağlıklarına karşı sorumlulukları vardır & 0.719 \\
M 44* & Dişlerimi firçalarken suyun boşa akmasının kimseye zararı olmaz & 0.716 \\
M 1 & Kendi kişisel bakım ve temizliğimi kendim yaparım & 0.708 \\
M 28 & Bazı insanların kendilerini diğerlerinden üstün görmeleri beni sinirlendirir & 0.693 \\
M 42* & Derslerde sağlıkla ilgili daha fazla bilgi verilmesine gerek yok & 0.672 \\
M 57* & Sağlığımdan anne-babam sorumludur & 0.644 \\
M 37 & İnsanların diğer canlılara karşı sorumluluğu vardır & 0.641 \\
M 21 & Kendi sağlığım kadar çevremdekilerin sağlığına da önem veririm & 0.638 \\
M 19* & Kendi güvenliğimden sorumlu değilim & 0.624 \\
M 17 & Vücudumu seviyorum & 0.563 \\
M 8 & Zamanı gelince aşılarımı olurum & 0.545 \\
M 11 & Çocuk olarak haklarımı biliyorum & 0.506 \\
M 23* & Spor yapmak bana zor gelir & 0.542 \\
M 30 & Kendi sağlığıma önem verdiğime inanıyorum & 0.456 \\
\hline
\end{tabular}


1. Faktörün Cronbach's Alpha Değeri $(\alpha)=0.965$ Ortalaması $=2.484$ Sorular Arası Ortalama Korelasyonu $=0.625$

Faktör 2: Çevre ve Güvenlik Sağlığı

M 2

Çöplerimi her zaman ayrıştırarak bir çöp kutusuna atarım

0.739

Biten pilleri her zaman pil atık kutusuna atarım

0.722

Geri dönüşümü dikkate alır, çöplerimi ayrıştırırım

0.715

Bana hediye olarak sağlıkla ilgili kitap verilmesinden hoşlanırım $\quad 0.712$

Hasta olmasam da doktora kontrole giderim

0.693

Arabaya bindiğimde mutlaka emniyet kemerimi bağlarım

0.677

Bir insan bana kaba davrandığında ona aynı şekilde karşılık vermem $\quad 0.646$

$\begin{array}{ll}\text { Alışverişe gitmeden önce alınacakları listelerim } & 0.629\end{array}$

Tehlikeli sokak aralarında arkadaşlarımla oyun oynamam

0.601

2. Faktörün Cronbach's Alpha Değgeri $(\alpha)=0.920$ Ortalaması $=2.280$ Sorular Arası Ortalama Korelasyonu $=0.562$

\section{Faktör 3: Bütünüyle Sağlıklı Bir İnsan}

M 43* Sağlıklı olmak için hastalıklardan korunmak gerekir $\quad 0.857$

M 55*

Sıvı yiyecekler daha hızlı sindirilir

0.857
0.785

Sağlığım ile ilgili bilgileri doktordan öğrenmek hoşuma gider $\quad 0.781$

M 52*

M 34*

M 50*

M 26* Aş1 olunca hasta olmam

İnsanların diğer canlılara göre genleri daha fazladır

\section{Faktörün Cronbach's Alpha Değeri $(\alpha)=0.870$ Ortalaması $=1.762$ Sorular Arası Ortalama} Korelasyonu $=0.464$

*Geleneksel sağlık ve sağlık eğitimine yönelik tutumu temsil eden bu maddeler, ölçeğin tersten okunmasıyla puanlanmıştır

Ölçeğin alt boyutları incelendiğinde, birinci faktör olan "Sağlık Sorumluluğu" faktörünün 17, ikinci faktör olan “Çevre ve Güvenlik Sağlı̆̆g” faktörünün 9 ve üçüncü faktör olan "Bütünüyle Sağlıklı Bir İnsan” faktörünün 8 maddeyi içerdiği görülmektedir. Birinci faktörü oluşturan maddelerin faktör yükleri 0.749 ile 0.456 arasında; ikinci faktörü oluşturan maddelerin faktör yükleri 0.739 ile 0.601 arasında; üçüncü faktörü oluşturan maddelerin faktör yükleri 0.857 ile 0.452 arasında değişmektedir.

Ölçeğin güvenirlik analizi için Cronbach alpha katsayısı 0.968 olarak hesaplanmıştır (Tablo 5). Bu değer, ölçme aracını oluşturan maddelerin kendi aralarında tutarlılık gösterip göstermediğini test etmek amacıyla kullanılmaktadır. Güvenirlik katsayısı 0 ile 1 arasında değişir ve bu değer 1'e yaklaştıkça güvenirlik artar (Tablo 5) (Ural ve Kılıç, 2006). 
Tablo 5: Güvenirlik Analizi Sonuçları

\begin{tabular}{ccccc}
\hline $\begin{array}{c}\text { Cronbach's Alpha Değeri } \\
(\boldsymbol{\alpha})\end{array}$ & Ortalama & Sorular arası Ortalama & Madde & Veri \\
0.968 & 2.260 & Korelasyon & Sayısı & Sayısı \\
& & 0.477 & 34 & 234 \\
\hline
\end{tabular}

Tablo 6: Madde İle Bütün Arasındaki İstatistikler

\begin{tabular}{|c|c|c|c|c|}
\hline $\begin{array}{l}\text { Madde } \\
\text { No }\end{array}$ & $\begin{array}{l}\text { Madde Silindiğinde } \\
\text { Ölçeğin Ortalaması }\end{array}$ & $\begin{array}{l}\text { Madde Silindiğinde } \\
\text { Ölçeğin Varyansı }\end{array}$ & $\begin{array}{l}\text { Madde İle Bütün } \\
\text { Arasındaki } \\
\text { Korelasyon }\end{array}$ & 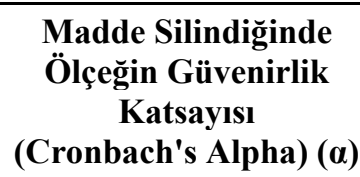 \\
\hline M 1 & 74.15 & 387.290 & 0.866 & 0.966 \\
\hline M 2 & 74.47 & 388.439 & 0.713 & 0.967 \\
\hline M 3 & 74.47 & 388.216 & 0.703 & 0.967 \\
\hline M 8 & 74.31 & 387.012 & 0.786 & 0.967 \\
\hline M 9 & 74.56 & 387.458 & 0.720 & 0.967 \\
\hline M 10 & 74.92 & 391.114 & 0.575 & 0.968 \\
\hline M 11 & 74.37 & 386.783 & 0.757 & 0.967 \\
\hline M 12 & 74.51 & 387.152 & 0.698 & 0.967 \\
\hline M 13 & 74.44 & 387.492 & 0.704 & 0.967 \\
\hline M 16 & 74.57 & 387.766 & 0.699 & 0.967 \\
\hline M 17 & 74.29 & 386.808 & 0.783 & 0.967 \\
\hline M 19 & 74.37 & 386.680 & 0.737 & 0.967 \\
\hline M 20 & 74.67 & 388.464 & 0.609 & 0.968 \\
\hline M 21 & 74.24 & 387.172 & 0.792 & 0.967 \\
\hline M 23 & 74.41 & 387.495 & 0.737 & 0.967 \\
\hline M 24 & 74.86 & 391.372 & 0.524 & 0.968 \\
\hline M 26 & 74.79 & 392.284 & 0.521 & 0.968 \\
\hline M 28 & 74.30 & 387.586 & 0.747 & 0.967 \\
\hline M 29 & 74.50 & 387.144 & 0.727 & 0.967 \\
\hline M 30 & 74.35 & 387.387 & 0.752 & 0.967 \\
\hline M 33 & 74.62 & 388.530 & 0.667 & 0.967 \\
\hline M 34 & 75.08 & 393.920 & 0.512 & 0.968 \\
\hline M 37 & 74.31 & 387.278 & 0.747 & 0.967 \\
\hline M 38 & 74.37 & 386.877 & 0.718 & 0.967 \\
\hline M 41 & 74.25 & 386.567 & 0.794 & 0.967 \\
\hline M 42 & 74.47 & 386.130 & 0.722 & 0.967 \\
\hline M 43 & 75.47 & 397.692 & 0.455 & 0.968 \\
\hline M 44 & 74.30 & 386.247 & 0.769 & 0.967 \\
\hline M 50 & 74.98 & 392.377 & 0.608 & 0.968 \\
\hline M 52 & 75.35 & 397.045 & 0.443 & 0.968 \\
\hline M 53 & 74.31 & 385.632 & 0.803 & 0.967 \\
\hline M 54 & 74.79 & 390.284 & 0.628 & 0.967 \\
\hline M 55 & 75.30 & 396.648 & 0.453 & 0.968 \\
\hline M 57 & 74.62 & 388.365 & 0.643 & 0.967 \\
\hline
\end{tabular}


Tablo 6'da ilk sütunda ilgili madde silindiğinde ölçeğin ortalaması, ikinci sütunda ilgili madde silindiğinde ölçeğin varyansı, üçüncü sütunda her bir madde ile bütün arasındaki korelasyon ve son sütunda ise ilgili madde silindiğinde ölçeğin güvenirlik katsayısı ( $\alpha$ ) yer almaktadır. Bu tabloya göre her bir madde ile bütün arasındaki korelasyon incelendiğinde düşük korelasyon görülmemektedir. Böylece ölçeğin güvenirliğini düşüren bir madde olmadığ1 söylenebilir. Son sütunda madde silindiğinde ölçeğin güvenirliğini yükselten bir maddeye de rastlanmamıştır. Bu durumda ölçekten herhangi bir maddenin çıkarılmasına gerek olmadığ1 düşünülebilir. Çalışmanın sonraki aşamasında madde ayırt edicilik analizi yapılmıştır. Bunun için ölçeğin toplam puanlarına göre oluşturulan \%27'lik alt grubun ve \%27’lik üst grubun madde ortalama puanları arasındaki farkların ilişkisiz t-testi kullanılarak sınanmıştır. Gruplar arasında istenen yönde gözlenen farkların anlamlı çıkması, testin iç tutarlılığının bir göstergesidir. Bu kapsamda öncelikle $\mathrm{N}=234$ için toplam puanlara göre $\% 27^{\prime}$ lik ( $\left.n=63\right)$ alt ve \%27 ( $\left.n=63\right)$ üst grup tanımlanmıştır. Bu grupların madde ortalama puanları için ilişkisiz t-testi uygulanmıştır. Her bir maddenin ayırt edicilik indeksine bakılmıştır. Çalışmada istatistiksel olarak 0.05 anlamlılık esas alınmıştır (Büyüköztürk, 2004) (Tablo 7).

Tablo 7: \%27 Alt ve \%27 Üst Gruplar İçin İlişkisiz T Testi Sonuçları

\begin{tabular}{|c|c|c|c|c|c|c|c|}
\hline Madde No & Grup & $\mathbf{N}$ & Ortalama & (X) Standart Sapma & Serbestlik Derecesi & $\mathbf{t}$ & $\mathbf{p}$ \\
\hline \multirow{2}{*}{ M 1} & Alt $\% 27$ & 63 & 1.87 & 0.992 & \multirow{2}{*}{124} & -9.019 & 0.000 \\
\hline & Üst $\% 27$ & 63 & 3.00 & 0.000 & & -9.019 & 0.000 \\
\hline \multirow{2}{*}{ M 2} & Alt $\% 27$ & 63 & 1.62 & 0.851 & \multirow{2}{*}{124} & -11.567 & 0.000 \\
\hline & Üst $\% 27$ & 63 & 2.92 & 0.272 & & -11.567 & 0.000 \\
\hline \multirow{2}{*}{ M 3} & Alt $\% 27$ & 63 & 1.60 & 0.871 & \multirow{2}{*}{124} & -11.226 & 0.000 \\
\hline & Üst $\% 27$ & 63 & 2.90 & 0.296 & & -11.226 & 0.000 \\
\hline \multirow{2}{*}{ M 8} & Alt $\% 27$ & 63 & 1.59 & 0.854 & \multirow{2}{*}{124} & -13.122 & 0.000 \\
\hline & Üst $\% 27$ & 63 & 3.00 & 0.000 & & -13.122 & 0.000 \\
\hline \multirow{2}{*}{ M 9} & Alt $\% 27$ & 63 & 1.37 & 0.725 & \multirow{2}{*}{124} & -14.553 & 0.000 \\
\hline & Üst $\% 27$ & 63 & 2.89 & 0.406 & & -14.553 & 0.000 \\
\hline \multirow{2}{*}{ M 10} & Alt $\% 27$ & 63 & 1.21 & 0.626 & \multirow{2}{*}{124} & -12.512 & 0.000 \\
\hline & Üst $\% 27$ & 63 & 2.63 & 0.655 & & -12.512 & 0.000 \\
\hline \multirow{2}{*}{ M 11} & Alt $\% 27$ & 63 & 1.60 & 0.890 & \multirow{2}{*}{124} & -12.198 & 0.000 \\
\hline & Üst $\% 27$ & 63 & 2.98 & 0.126 & & -12.198 & 0.000 \\
\hline \multirow{2}{*}{ M 12} & Alt $\% 27$ & 63 & 1.44 & 0.757 & \multirow{2}{*}{124} & -16.304 & 0.000 \\
\hline & Üst $\% 27$ & 63 & 3.00 & 0.000 & & -16.304 & 0.000 \\
\hline \multirow{2}{*}{ M 13} & Alt $\% 27$ & 63 & 1.51 & 0.840 & \multirow[t]{2}{*}{124} & -12.203 & 0.000 \\
\hline & Üst $\% 27$ & 63 & 2.90 & 0.346 & & -12.203 & 0.000 \\
\hline \multirow{2}{*}{ M 16} & Alt $\% 27$ & 63 & 1.51 & 0.859 & \multirow{2}{*}{124} & -13.217 & 0.000 \\
\hline & Üst \%27 & 63 & 2.97 & 0.177 & & -13.217 & 0.000 \\
\hline M 17 & Alt $\% 27$ & 63 & 1.60 & 0.890 & 124 & -12.198 & 0.000 \\
\hline
\end{tabular}




\begin{tabular}{|c|c|c|c|c|c|c|c|}
\hline & Üst $\% 27$ & 63 & 2.98 & 0.126 & & -12.198 & 0.000 \\
\hline \multirow{2}{*}{ M 19} & Alt $\% 27$ & 63 & 1.46 & 0.858 & \multirow{2}{*}{124} & -12.626 & 0.000 \\
\hline & Üst \%27 & 63 & 2.94 & 0.353 & & -12.626 & 0.000 \\
\hline \multirow{2}{*}{ M 20} & Alt \%27 & 63 & 1.30 & 0.733 & \multirow{2}{*}{124} & -13.163 & 0.000 \\
\hline & Üst \%27 & 63 & 2.83 & 0.555 & & -13.163 & 0.000 \\
\hline \multirow{2}{*}{ M 21} & Alt \%27 & 63 & 1.73 & 0.971 & \multirow{2}{*}{124} & -9.800 & 0.000 \\
\hline & Üst $\% 27$ & 63 & 2.97 & 0.252 & & -9.800 & 0.000 \\
\hline \multirow{2}{*}{ M 23} & Alt \%27 & 63 & 1.60 & 0.890 & \multirow{2}{*}{124} & -11.945 & 0.000 \\
\hline & Üst \%27 & 63 & 2.97 & 0.177 & & -11.945 & 0.000 \\
\hline \multirow{2}{*}{ M 24} & Alt \%27 & 63 & 1.29 & 0.658 & \multirow{2}{*}{124} & -11.063 & 0.000 \\
\hline & Üst $\% 27$ & 63 & 2.67 & 0.741 & & -11.063 & 0.000 \\
\hline \multirow{2}{*}{ M 26} & Alt $\% 27$ & 63 & 1.49 & 0.859 & \multirow{2}{*}{124} & -8.965 & 0.000 \\
\hline & Üst \%27 & 63 & 2.71 & 0.658 & & -8.965 & 0.000 \\
\hline \multirow{2}{*}{ M 28} & Alt \%27 & 63 & 1.70 & 0.891 & \multirow{2}{*}{124} & -11.589 & 0.000 \\
\hline & Üst $\% 27$ & 63 & 3.00 & 0.000 & & -11.589 & 0.000 \\
\hline \multirow{2}{*}{ M 29} & Alt $\% 27$ & 63 & 1.46 & 0.779 & \multirow{2}{*}{124} & -14.005 & 0.000 \\
\hline & Üst \%27 & 63 & 2.94 & 0.304 & & -14.005 & 0.000 \\
\hline \multirow{2}{*}{ M 30} & Alt \%27 & 63 & 1.59 & 0.891 & \multirow{2}{*}{124} & -11.596 & 0.000 \\
\hline & Üst \%27 & 63 & 2.95 & 0.280 & & -11.596 & 0.000 \\
\hline \multirow{2}{*}{ M 33} & Alt \%27 & 63 & 1.44 & 0.778 & \multirow{2}{*}{124} & -11.896 & 0.000 \\
\hline & Üst \%27 & 63 & 2.83 & 0.493 & & -11.896 & 0.000 \\
\hline \multirow{2}{*}{ M 34} & Alt $\% 27$ & 63 & 1.22 & 0.522 & \multirow{2}{*}{124} & -10.113 & 0.000 \\
\hline & Üst \%27 & 63 & 2.46 & 0.820 & & -10.113 & 0.000 \\
\hline M 37 & Alt \%27 & 63 & 1.65 & 0.883 & 124 & -11.391 & 0.000 \\
\hline ו & Üst $\% 27$ & 63 & 2.97 & 0.252 & 124 & -11.391 & 0.000 \\
\hline M 38 & Alt \%27 & 63 & 1.52 & 0.913 & 124 & -12.101 & 0.000 \\
\hline & Üst \%27 & 63 & 2.97 & 0.252 & 124 & -12.101 & 0.000 \\
\hline M 41 & Alt $\% 27$ & 63 & 1.63 & 0.938 & 124 & -10.891 & 0.000 \\
\hline 10141 & Üst \%27 & 63 & 2.97 & 0.252 & 124 & -10.891 & 0.000 \\
\hline M 42 & Alt \%27 & 63 & 1.33 & 0.803 & 124 & -15.415 & 0.000 \\
\hline 10142 & Üst \%27 & 63 & 2.97 & 0.252 & 124 & -15.415 & 0.000 \\
\hline M 43 & Alt $\% 27$ & 63 & 1.03 & 0.309 & 124 & -8.443 & 0.000 \\
\hline 10145 & Üst \%27 & 63 & 2.14 & 0.998 & 124 & -8.443 & 0.000 \\
\hline M 44 & Alt \%27 & 63 & 1.57 & 0.875 & 124 & -12.964 & 0.000 \\
\hline 10144 & Üst \%27 & 63 & 3.00 & 0.000 & 124 & -12.964 & 0.000 \\
\hline M 50 & Alt \%27 & 63 & 1.25 & 0.567 & 124 & -11.648 & 0.000 \\
\hline & Üst \%27 & 63 & 2.54 & 0.668 & & -11.648 & 0.000 \\
\hline M 52 & Alt $\% 27$ & 63 & 1.11 & 0.444 & 124 & -8.037 & 0.000 \\
\hline$M 52$ & Üst \%27 & 63 & 2.21 & 0.986 & 124 & -8.037 & 0.000 \\
\hline M 53 & Alt \%27 & 63 & 1.43 & 0.837 & 124 & -14.903 & 0.000 \\
\hline M53 & Üst \%27 & 63 & 3.00 & 0.000 & 124 & -14.903 & 0.000 \\
\hline M 54 & Alt \%27 & 63 & 1.35 & 0.722 & 124 & -13.512 & 0.000 \\
\hline 1154 & Üst \%27 & 63 & 2.79 & 0.446 & 124 & -13.512 & 0.000 \\
\hline M 55 & Alt \%27 & 63 & 1.25 & 0.567 & 124 & -7.456 & 0.000 \\
\hline ivi & Üst \%27 & 63 & 2.29 & 0.941 & & -7.456 & 0.000 \\
\hline M 5 & Alt \%27 & 63 & 1.33 & 0.741 & 124 & -13.787 & 0.000 \\
\hline 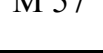 & Üst \%27 & 63 & 2.86 & 0.470 & 124 & -13.787 & 0.000 \\
\hline
\end{tabular}


Madde ayırt ediciliği açısından 0.05 anlamlılık düzeyinde $\mathrm{p}<0.05$ ise gruplar arasındaki fark önemlidir (Ural, Kılıç, 2006). Tablo 7'ye bakıldığında bu duruma uymayan maddeye rastlanmadığından alt \%27 ve üst \%27’lik gruplar arasındaki farkın önemli olduğu ve maddelerin bu haliyle ölçekte yer alabileceği söylenebilir.

Diğer bir bakış açısıyla hesaplanan $\mathrm{t}$ değeri teorik $\mathrm{t}$ değerinden büyük ise gruplar arasındaki fark önemlidir. Teorik $\mathrm{t}$ değeri, belirlenmiş (0.05) anlamlılık düzeyine ve serbestlik derecesine (124) karşılık gelen t-tablo değerine göre hesaplanır. Çalışma için teorik t değeri 1.97'dir. Buna göre hesaplanan t değerleri 1.97'den büyük ise gruplar arasındaki fark anlamlıdır (Ural, Kılıç, 2006). Tablo 7'ye bakıldığında bu duruma uymayan maddeye rastlanmamıştır. Maddeler için hesaplanan t değeri, teorik t değerinden (1.97) büyüktür. $\mathrm{Bu}$ durumda bu maddeler için alt \%27 ve üst \%27’lik gruplar arasındaki farkın önemli olduğu, dolayısıyla bu maddelerin ölçekte kullanılabileceği söylenebilir.

\section{Sonuç ve Öneriler}

Türkiye'de sağlık eğitimi literatürü örnekleri incelendiğinde önemli adımlar atıldığı görülmektedir (Ak, Çelen, Özen, Tabak ve Piyal, 2006; Alkan ve ark., 2005; Belek, 1998; Cerrah ve Ayaş, 2003; Doğan, 2006; Man ve Balc1, 2006; Sağlam, 1996). Ancak ULAKBİM veri tabanında yapılan incelemede, Türkiye'de ilköğretim öğrencilerine yönelik geliştirilmiş bir tutum ölçeğine rastlanmamıştır (ULAKBİM, 2013). Son yıllarda sağlığı koruma girişimlerinde daha doğru ve geçerli bilgi elde edebilmek için bireylerin sağlık davranışlarının; kültürlerine uygun, geçerli ve güvenilir araçlarla değerlendirilmesi gereği ortaya çıkmıştır (Bahar ve arkadaşları, 2008). Türkiye şartlarına özel böyle bir tutum ölçeği ile öğrenci tutumlarıyla ilgili genel bilgilerin yanı sıra daha özel bilgiler de ölçülebilir. $\mathrm{Bu}$ çalışma, bu yönüyle hem sağlık eğitimi literatürüne katkı saylayabilir hem de bu eğitimi verecek öğretmenlere yol gösterebilir. Var olan eğitimin dönütü niteliği taşıyan bu çalışma ile öğrenci sağlık tutumlarının genel bir profilini çizmeye yardımcı olabilir.

Yapılan analizler çerçevesinde, 34 maddelik ölçeğin genel bir faktöre sahip olduğu ve Varimax döndürmesi sonrası özdeğeri 1'den yüksek üç faktör altında toplandığ1 görülmüştür. $\mathrm{Bu}$ faktörler; sağlık sorumluluğu, çevre ve güvenlik sağlığı ve bütünüyle sağlıklı bir insan olarak adlandırılmıştır. Sağlık sorumluluğu faktörü, Yarham (1994) çalışmasında da adı geçen ve öğrenciye sağlık eğitimiyle kazandırılmak istenen bir değerdir. Sağlık sorumluluğu faktörü, Kaya ve arkadaşlarının (2008) çalışmasında kullandıkları Pender'in Sağlığı Geliştirici Yaşam Tarzı ölçeğinde de yer almaktadır ve öğretim elemanlarının en az uyguladıkları sağlık davranışlarından biridir. Bu yaklaşım, sağlık denince akla sadece bedensel sağlığın gelmediği, 
kendisi kadar çevresinin sağlığından da sorumlu olan, bu konuda yetki ve sorumluluk alabilen bireylerin yer aldığı bir sağlık eğitimi anlayışını temsil etmektedir. Böylece bu öğrenciye ait sağlık tutum ölçeğinden elde edilecek veriler, kendisinin ve çevresinin sağlığ1 ile ilgili sorumluluğa sahip olup olmadığına dair bilgi verebilir.

Ölçeğin güvenirlik analizinde, Cronbach alpha katsayısı 0.968 'dir ve ölçekten silindiğinde güvenirliği yükselten bir maddeye rastlanmamıştır. Madde ayırt edicilik analizlerinde; ölçeğin toplam puanlarına göre oluşturulan \%27'lik alt ve üst grubun madde ortalama puanları arasındaki farkın önemli olduğu ve maddelerin ölçekte bu halleriyle kullanılabileceği söylenebilir (0.05 anlamlılık esas alınmıştır).

Sağlık eğitimine yönelik öğrenci tutumlarını belirlemek için hazırlanan bu ölçeğin, yapılan analizler neticesinde ölçme amacına uygun olduğu ve ölçülmek istenen alanı temsil ettiği söylenebilir.

Ölçeğin yapı geçerliliği için açımlayıcı faktör analizi yapılmış olsa da daha detaylı analizler için sonraki çalışmalarda doğrulayıcı faktör analizleri de yapılmalıdır. Farklı sınıf düzeylerinde, farklı ortamlarda tekrarlanması ve araştırmaya yeni verilerin katılması yerinde olacaktır.

Bir sonraki aşamada Türkiye'de sağlı eğitimi konusunda belirlenmiş ve uygulanmakta olan bir yaklaşımın olup olmadığı, varsa bunun öğrenciye nasıl yansıdığı hakkında daha detaylı çalışmalar yapılmalıdır.

\section{Kaynaklar}

Ak, Ş., Çelen, Ü., Özen, Y., Tabak, R.S., Piyal, B. (2006). Ankara merkez ilçeler ilköğretim okulları çalışanlarının sağlık davranışları. TSK Koruyucu Hekimlik Bülteni, 5(2), 8393.

Akdur, R. (2003). Sağlık sektörü temel kavramlar, Türkiye ve Avrupa Birliği'nde durum ve Türkiye'nin birliğe uyumu. Editör: Yrd. Doç. Dr. M. Nail Alkan. Ankara Üniversitesi Avrupa Toplulukları Araştırma ve Uygulama Merkezi Araştırma Dizisi No: 17. Ankara: Ankara Üniversitesi Basımevi. ISBN: 975-482-608-0.

Alkan, E., Ertem, A.A., Hatemoğlu, E., Hülür, Ü. ve Mollahaliloğlu, S. (2005). Mevcut durum raporu. Okullarda sağlık eğitimi. T.C. Sağlık Bakanlı̆̆ı, Refik Saydam Hıfzıssıhha Merkezi Başkanlığı, Hıfzıssıhha Mektebi Müdürlüğü, 14 Aralık.

Bahar, Z., Beşer, A., Gördes, N., Ersin, F. Ve Kıssal, A. (2008). Sağlıklı yaşam biçimi davranışları ölçeği II'nin geçerlik ve güvenirlik çalışması. C.Ü. Hemşirelik Yüksekokulu Dergisi, 12(19), 1-13.

Bay, E., Mert, O., Alyılmaz, S. ve Albayrak, F. (2012). Eski Türk eserlerine ilişkin tutum ölçeği geliştirilmesi. Uluslararası Türkçe Edebiyat Kültür Eğitim Dergisi, 1/2, 70-82. 
Belek, İ. (1998). Sağlıkta eşitsizlik: Önlenebilir ve kabul edilemez bir politik ekonomi sorunu. Toplum ve Hekim, 13 (2), 96-104.

Büyüköztürk, Ş. (2004). Sosyal Bilimler için veri analizi el kitabı; istatistik, araştırma deseni, SPSS uygulamaları ve yorum. (4. Baskı) Ankara: PegemA Yayıncılık, s. 117-131.

Cerrah, L., Ayaş, A. (2003). Meslek liselerinde görev yapan biyoloji öğretmenlerinin karşılaştıkları problemler. Biyoloji ve sağlık bilgisi öğretim programına bir bakış. Milli Ĕ̈itim Dergisi, 159, 149-159.

Çirkinoğlu-Şekercioğlu, A. G. (2011). Akran öğretimi yönteminin öğretmen adaylarının elektrostatik konusundaki kavramsal anlamalarına ve tutumlarına etkisi. Balıkesir Üniversitesi, Fen Bilimleri Enstitüsü Doktora Tezi, Balıkesir.

Doğan, T. (2006). Üniversite öğrencilerinin iyilik halinin incelenmesi. H. ̈̈. Eğitim Fakültesi Dergisi, 30, 120-129.

Fosse, E. ve Roeiseland, A. (1999). From vision to reality? The Ottawa-Charter in Norwegian health policy. Internet Journal of Health Promotion, URL: http://www.rhpeo.org/ijhparticles/1999/1/index.htm (Erişim: 28.05.2008).

Güler, S. ve Yöndem, Z. (2007). Ergenlik ve cinsel sağlı eğitimi ile ilgili grup rehberliğinin 6. sınıf öğrencilerinin bilgi ve tutumlarına etkisi. Ilköğretim Online, 6 (1), 2-10.

Güven, B. ve Uzman, E. (2006). Ortaöğretim coğrafya dersi tutum ölçeği geliştirme çalışması. Kastamonu Ĕ̈itim Dergisi, 14(2), 527-536.

İslamoğlu, G. ve Börü, D. (2007). Politik davranış boyutları: Bir ölçek geliştirme çalışması. Akdeniz I.I. .B.F Dergisi, 14, 135-153.

Kan, A. ve Akbaş, A. (2005). Lise öğrencilerinin kimya dersine yönelik tutum ölçeği geliştirme çalışması. Mersin Üniversitesi Eğitim Fakültesi Dergisi, 1(2), 227- 237.

Kaya, F., Ünüvar, R., Bıçak, A., Yorgancı, E., Funda Öz, B.Ç. ve Kankaya, F.C. (2008). Öğretim elemanlarının sağlığı geliştirme davranışları ve etkileyen etmenlerin incelenmesi. TSK Koruyucu Hekimlik Bülteni, 7 (1), 59-64.

Koçakoğlu, M. ve Türkmen L. (2010). Biyoloji dersine yönelik tutum ölçeği geliştirilmesi. Ahi Evran Üniversitesi Ë̆itim Fakültesi Dergisi, 11(2), 229-245.

Kurnaz, M.A. ve Yiğit, N. (2010). Fizik tutum ölçeği: Geliştirilmesi, geçerliliği ve güvenilirliği. Necatibey Eğitim Fakültesi Elektronik fen ve Matematik Eğitimi Dergisi, 4(1), 29-49.

Man, F. ve Balc1, A. (2006). Postmodern bir dönemde modern bir pratik olarak sağlik. V. Uluslararası Bilgi, Ekonomi ve Yönetim Kongresi, Kocaeli Üniversitesi, 3-5 Kasım, Kocaeli.

McQueen, D.V. ve Jones, C.M. (2007). Global perspectives on health promotion effectiveness. New York, USA: Springer Science \& Business Media.

Rootman, I., Goodstadt, M., Hyndman, B., McQueen, D.V., Potvin, L., Springett, J. ve Ziglio, E. (2011). Sağlığın teşviki ve geliştirilmesi alanındaki değerlendirmeler, ilkeler ve bakış açıları. Dünya Sağlık Örgütü (DSÖ), Bölgesel Yayınlar, Avrupa Serisi, No: 92. 2001 yılında yayınlanmıştır. Ed.: Akdağ, R., Erkoç, Y., Çom, S., Keskinkılıç, B., Karkaya, K. 
Türkiye Cumhuriyeti Sağlık Bakanlığı, Temel Sağlık Hizmetleri Genel Müdürlüğü tarafından çevrilmiştir. Bakanlık Yayın no: 815, Ankara: Anıl Matbaacılık.

Sağlam, N. (1996). Ortaöğretimde Sağlık Bilgisi dersinin niteliği ve öğrencilerin derse ilgileri. Hacettepe Üniversitesi Ĕ̆itim Fakültesi Dergisi, 12, 201-206.

Srof, B. J. ve Velsor-Friedrich, B. (2006). Health promotion in adolescents: A review of Pender's health promotion model. Nursing Science Quaterly, 19(4), 366-373.

Tavşancıl, E. ve Keser, H. (2002). İnternet kullanımına yönelik Likert tipi bir tutum ölçeğinin geliştirilmesi. Eğitim Bilimleri ve Uygulama, 1(1), 79-100.

Tekindal, S. (2009). Duyuşsal özelliklerin ölçülmesi için araç oluşturma. Ankara: Pegem Akademi.

Terzi, A. R. ve Tezci, E. (2007). Necatibey Eğitim Fakültesi öğrencilerinin öğretmenlik mesleğine ilişkin tutumları. Kuram ve Uygulamada Ĕ̆itim Yönetimi, 13(52), 593-614.

Tokuç, B. ve Berberoğlu, U. (2007). Edirne merkez ilçe ilköğretim okullarında çalışan öğretmenlerde sağlığı geliştirici davranışlar. TSK Koruyucu Hekimlik Bülteni, 6(6), 421426.

Turan, S. ve Bahar-Özvarış, Ş. (2006). Altındağ Halk Eğitim Merkezinde kadın kursiyerlerin "kadın sağlığı" konusunda bilgi düzeylerini belirlemek için ölçme aracı geliştirme çalışması. Toplum Hekimliği Bülteni, 25(1), 5-11.

Türkiye Cumhuriyeti (T.C.) Anayasası 56. Maddesi (1982). A: Sağlık hizmetleri ve çevrenin korunmas1. URL: http://www.tbmm.gov.tr/develop/owa/anayasa.uc?p1=56 (Erişim: 01.02.2013).

T.C. Milli Eğitim Bakanlığı (MEB) Talim ve Terbiye Kurulu Başkanlığı (TTKB), (2009). İlköğretim öğretim programları URL: http://ttkb.meb.gov.tr/www/ogretimprogramlari/icerik/72 (erişim 01.02.2013).

T.C. Milli Eğitim Bakanlığı (MEB) Talim ve Terbiye Kurulu Başkanlığı (TTKB), (2012). Ortaöğretim sağlı bilgisi dersi öğretim programı. URL: http://ttkb.meb.gov.tr/www/ogretim-programlari/icerik/72 (erişim 01.02.2013).

Ulusal Akademik Ăg ve Bilgi Merkezi (ULAKBİM), Cahit Arf Bilgi Merkezi (CABİM), (2013). ULAKBİM Keşif. URL: www.ulakbim.gov.tr/cabim/ (erişim 01.02.2013).

Ulusoy-Gökkoca, F. Z. (2001). Sağlık eğitimi açısından temel ilkeler. Sürekli Tıp Eğitimi Dergisi, 10(10), 371-374. URL: http://www.saglikplatformu.com/statik/saglikegitimi.pdf (Erişim: 15.12.2012).

Ural, A. ve Kılıç, İ. (2006). Bilimsel araştırma süreci ve SPSS ile veri analizi; SPSS 10.0-12.0 for Windows. (2. Bask1) Ankara: Detay Yayınc1l1k, s.281-294.

Whalen, S., Splendorio, D. ve Chiariello, S. (2007). Tools for teaching health, interactive strategies to promote health literacy and life skills in adolescents and young adults. San Francisco, USA: John Wiley \& Sons, Inc. Jossey-Bass.

World Health Organization (WHO). (1998). Health promotion glossary. Geneva: WHO/HPR/HEP/98.1. URL: http://www.who.int/healthpromotion/about/HPR\%20Glossary\%201998.pdf (Erişim: 02 Şubat 2013). 
World Health Organization (WHO). (2013a). Health education. URL: http://www.who.int/topics/health_education/en/ (Erişim: 02 Şubat 2013).

World Health Organization (WHO). (2013b). Health promotion. URL: http://www.who.int/topics/health_promotion/en/ (Erişim: 02 Şubat 2013)

Yarham, C.L. (1994). Health education and promotion: A school programme for adolescents. Promotion \& Education, 1(6). URL: http://ped.sagepub.com (Erişim: 17 Aralık 2009)

Yeşilyurt, S. ve Gül, Ş. (2009). Biyoloji tutum ölçeği. Erzincan Eğitim Fakültesi Dergisi, 11(2), 239-258.

Yurtsever-Kılıçgün, M. ve Oktay, A. (2011). Çocuk haklarına yönelik ebeveyn tutum ölçeğinin geliştirilmesi ve standardizasyonu. Buca Eğitim Fakültesi Dergisi, 31, 1-22.

Zöllner, H., Stoddart, G. ve Selby Smith, C. (2003). Learning to live with health economics. Chapter V Useful economic tools. Copenhagen: Who Regional Office for Europe. URL: http://new.paho.org/hq/documents/events/antigua06/Libro_OMS_Economia_Salud_Zol lner_Stoddart_5.pdf (Erişim: 02 Şubat 2013). 


\section{EK: Öğrenci Sağlık Tutum Ölçeği}

Sevgili Öğrenci,

Aşağıda sağlıkla ilgili çeşitli cümleler yer almaktadır. Bu cümlelerden sana uygun olanlara

"Katılıorum", aynı fikirde olmadıklarına "Katılmıyorum", konu hakkında fikrin yoksa yada kararsızsan

“Kararsızım” seçeneklerinden yalnızca birine işaret $(\checkmark)$ koymanı istiyoruz. Şimdiden teşekkür ediyoruz.

Yard. Doç. Dr. Sami ÖZGÜR- Arş. Gör. Fatma ÇILDIR PELITOĞLU

\begin{tabular}{|c|c|c|c|c|}
\hline & & 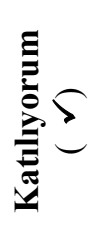 & 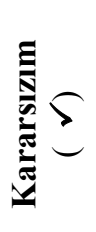 & 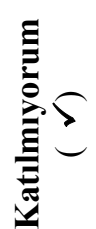 \\
\hline 1 & Sağlığım için yapmam gerekenleri öğrenmeyi seviyorum & & & \\
\hline 2 & Çöplerimi her zaman ayrıştırarak bir çöp kutusuna atarım & & & \\
\hline 3 & Alışverişe gitmeden önce alınacakları listelemek hoşuma gidiyor & & & \\
\hline 4 & Zamanı gelince aşılarımı olurum & & & \\
\hline 5 & Biten pilleri her zaman atık pil kutusuna atarım & & & \\
\hline 6 & Hasta değilsem doktora kontrole gitmek istemiyorum & & & \\
\hline 7 & Çocuk olarak haklarımı bilmiyorum & & & \\
\hline 8 & Bana hediye olarak sağlıkla ilgili kitap verilmesinden hoşlanırım & & & \\
\hline 9 & Tehlikeli sokak aralarında arkadaşlarımla oyun oynamam & & & \\
\hline 10 & Geri dönüşümü dikkate alır, çöplerimi ayrıştırırım & & & \\
\hline 11 & Vücudumu sevmiyorum & & & \\
\hline 12 & Kendi güvenliğimden sorumlu değilim & & & \\
\hline 13 & Sadece ekonomik öneme sahip bitki ve hayvanlar korunma altına alınmalıdır & & & \\
\hline 14 & Çevremdekilerin sağlığına önem vermek hoşuma gidiyor & & & \\
\hline 15 & Spor yapmaktan hoşlanmıyorum & & & \\
\hline 16 & Kişisel bakım ve temizliğimi kendim yapmayı sevmiyorum & & & \\
\hline 17 & Bazı insanların kendilerini diğerlerinden üstün görmelerine üzülüyorum & & & \\
\hline 18 & Arabaya bindiğimde mutlaka emniyet kemerimi bağlarım & & & \\
\hline 19 & Kendi sağlığıma önem verdiğime inanıyorum & & & \\
\hline 20 & Öğretmenler okulda cinsel eğitim vermemeli çünkü bu konular özeldir & & & \\
\hline 21 & Bir insan bana kaba davrandığında ona aynı şekilde karşılık vermem & & & \\
\hline 22 & Aş1 olunca hiç hasta olmam & & & \\
\hline 23 & İnsanların diğer canlılara karşı sorumluluğu yoktur & & & \\
\hline 24 & Trafik kurallarına sadece sürücüler uymak zorundadır & & & \\
\hline 25 & İnsanların kendi sağlıklarına karşı sorumlulukları vardır & & & \\
\hline 26 & Derslerde sağlikla ilgili bilgi verilmesinden hoşlanmıyorum & & & \\
\hline 27 & Sağlıklı olmak için hastalıklardan korunmak gerekir & & & \\
\hline 28 & Dişlerimi firçalarken suyun boşa akmasının kimseye zararı olmaz & & & \\
\hline 29 & İnsanların diğer canlılara göre genleri daha fazladır & & & \\
\hline 30 & Sağlı̆̆ım ile ilgili bilgileri doktordan öğrenmek hoşuma gider & & & \\
\hline 31 & Ellerimi yıkamaktan hoşlanmıyorum & & & \\
\hline 32 & S1v1 yiyecekler daha hızlı sindirilir & & & \\
\hline 33 & Sağlığımdan anne-babam sorumludur & & & \\
\hline 34 & İkizlerin genleri aynı olduğu için mikroplara karşı bağışıklık sistemleri de aynıdır & & & \\
\hline
\end{tabular}

